\title{
Identification of Lynch Syndrome Carriers among Patients with Small Bowel Adenocarcinoma
}

\author{
Ariadna Sánchez $\left.{ }^{1}{ }^{(}\right)$, Luis Bujanda ${ }^{2}{ }^{\mathbb{D}}$, Miriam Cuatrecasas ${ }^{3}{ }^{\circledR}$, Alex Bofill ${ }^{1}$, Cristina Alvarez-Urturi ${ }^{4}$, \\ Goretti Hernandez ${ }^{5}$, Lara Aguilera ${ }^{6}$, Sabela Carballal ${ }^{1}{ }^{1}$, Joan Llach ${ }^{1}$, Cristina Herrera-Pariente ${ }^{1}{ }^{10}$, \\ Mar Iglesias ${ }^{7}$, Liseth Rivero-Sánchez ${ }^{1}{ }^{\mathbb{D}}$, Gerhard Jung ${ }^{1}{ }^{10}$, Lorena Moreno ${ }^{1}$, Teresa Ocaña ${ }^{1}$, Carolina Bayarri ${ }^{1}$, \\ Maria Pellise $^{1}$, Antoni Castells ${ }^{1}\left(\mathbb{D}\right.$, Sergi Castellví-Bel ${ }^{1}\left[\right.$, Francesc Balaguer ${ }^{1}\left(\mathbb{D}\right.$ and Leticia Moreira ${ }^{1, *}$ (i)
}

check for

updates

Citation: Sánchez, A.; Bujanda, L.; Cuatrecasas, M.; Bofill, A.; Alvarez-Urturi, C.; Hernandez, G.; Aguilera, L.; Carballal, S.; Llach, J.; Herrera-Pariente, C.; et al.

Identification of Lynch Syndrome Carriers among Patients with Small Bowel Adenocarcinoma. Cancers 2021, 13, 6378. https://doi.org/10.3390/ cancers 13246378

Academic Editors: Paola Izzo and Francesca Duraturo

Received: 23 November 2021 Accepted: 14 December 2021 Published: 20 December 2021

Publisher's Note: MDPI stays neutral with regard to jurisdictional claims in published maps and institutional affiliations.

Copyright: (c) 2021 by the authors. Licensee MDPI, Basel, Switzerland. This article is an open access article distributed under the terms and conditions of the Creative Commons Attribution (CC BY) license (https:// creativecommons.org/licenses/by/ $4.0 /)$.
1 Department of Gastroenterology, Hospital Clínic Barcelona, Centro de Investigación Biomédica en Red en Enfermedades Hepáticas y Digestivas (CIBEREHD), IDIBAPS (Institut d'Investigacions Biomèdiques August Pi i Sunyer), University of Barcelona, 08036 Barcelona, Spain; asanchezg@clinic.cat (A.S.); BOFILL@clinic.cat (A.B.); carballal@clinic.cat (S.C.); JLLACHR@clinic.cat (J.L.); cristina.herrera@ciberehd.org (C.H.-P.); LRIVERO@clinic.cat (L.R.-S.); JUNG@clinic.cat (G.J.); LOMORENO@clinic.cat (L.M.); MOCANA@clinic.cat (T.O.); cbayarri@clinic.cat (C.B.); mpellise@clinic.cat (M.P.); CASTELLS@clinic.cat (A.C.); SBEL@clinic.cat (S.C.-B.); fprunes@clinic.cat (F.B.)

2 Department of Gastroenterology, Biodonostia Health Research Institute, Centro de Investigación Biomédica en Red en Enfermedades Hepáticas y Digestivas (CIBEREHD), Universidad del País Vasco (UPV/EHU), 20014 San Sebastián, Spain; luis.bujanda@osakidetza.net

3 Department of Pathology, Hospital Clínic Barcelona, Centro de Investigación Biomédica en Red en Enfermedades Hepáticas y Digestivas (CIBEREHD), IDIBAPS (Institut d'Investigacions Biomèdiques August Pi i Sunyer), University of Barcelona, 08036 Barcelona, Spain; mcuatrec@clinic.cat

4 Department of Gastroenterology, IMIM (Hospital del Mar Medical Research Institute), Barcelona Hospital del Mar, 08003 Barcelona, Spain; 98907@hospitaldelmar.cat

5 Department of Gastroenterology, Hospital Universitario de Canarias, 38320 Tenerife, Spain; cghmesa@gmail.com

6 Department of Gastroenterology, Vall d'Hebron Research Institute, 08035 Barcelona, Spain; laraaguilera88@gmail.com

7 Department of Pathology, IMIM (Hospital del Mar Medical Research Institute), Barcelona Hospital del Mar, 08003 Barcelona, Spain; miglesiascoma@psmar.cat

* Correspondence: lmoreira@clinic.cat; Tel.: +34-93-227-5739; Fax: +34-93-227-5589

Simple Summary: Small bowel adenocarcinoma (SBA) is associated with Lynch syndrome (LS). This is the first study to evaluate the identification of LS patients based on mismatch repair deficiency (MMRd) tumor among SBA. The authors found a $21.3 \%$ prevalence of MMRd tumors and a $10.1 \%$ prevalence of LS. A germline mutation was identified in $60 \%$ of patients with a MMRd tumor. This data suggests that universal tumor MMR testing among SBA patients should be implemented for the identification of LS.

Abstract: Background: Small bowel adenocarcinoma (SBA) is a rare disease which can be associated with Lynch syndrome (LS). LS tumors are characterized by the presence of microsatellite instability (MSI) and/or the loss of mismatch repair (MMR) protein expression. In SBA, the frequency of MMR deficient (MMRd) tumors varies from 5\% to 35\%. This study aims to describe the prevalence of LS carriers among patients with MMRd small bowel adenocarcinomas. Methods: A multicenter retrospective study with identification and MMR testing of all consecutive SBA between 2004 and 2020 in a multicenter Spanish study. Demographical data, tumor characteristics, follow-up and survival information were collected. Germline testing was driven by identification of MMRd tumors. Results: A total of 94 individuals diagnosed with SBA were recruited. We observed 20 (21.3\%) MMRd tumors. In 9/15 (60\%) patients with MMRd tumors, a pathogenic variant was identified (three MLH1, four MSH2, one MSH6 and one PMS2). Accordingly, the prevalence of LS among all SBA cases was $10.1 \%$. Conclusions: More than one-fifth of SBA display MMRd and in more than a half is due to LS. Our data supports the implementation of universal MMR tumor testing among SBA for the identification of LS families.

Keywords: Lynch syndrome; small bowel adenocarcinoma; hereditary cancer 


\section{Introduction}

Small bowel adenocarcinoma (SBA) is a rare disease [1]. Although the small bowel represents $90 \%$ of the surface area from the gastrointestinal tract, these tumors represent less than $5 \%$ of all malignant gastrointestinal neoplasms [2], with a low lifetime risk $(0.3 \%)$ in the general population. Symptoms are non-specific and generally appear at advanced stages. This late presentation delays diagnoses and results in poor prognoses, with a fiveyear overall survival of less than $30 \%$ [3]. Certain medical conditions have been described as risk factors for SBA, including celiac disease, Crohn's disease and some hereditary cancer syndromes (i.e., familial adenomatous polyposis (FAP), Peutz-Jeghers syndrome and Lynch syndrome (LS)) [4-7].

LS is caused by a germline pathogenic variant in a DNA mismatch repair (MMR) gene (MLH1, MSH2, MSH6, PMS2 and $3^{\prime}$ end of EPCAM) and is characterized by an increased risk of cancer, especially colorectal and endometrial cancer $[8,9]$. LS tumors are characterized by the presence of microsatellite instability (MSI) and/or the loss of MMR protein expression, both considered hallmarks of this disorder [10]. In LS patients, the SBA lifetime cumulative risk rises to $4.2 \%[11,12]$.

In SBA, the frequency of MMR deficient (MMRd) tumors varies from $5 \%$ to $35 \%$ and it is an independent good prognostic factor [13-17]. However, no comprehensive studies have been conducted to identify LS from SBA tumors with altered MMR protein expression.

Identifying LS carriers is of special interest as these patients and their relatives could benefit by undergoing cancer preventive strategies that reduce their cancer incidence and mortality. This study aims to identify patients with LS among those diagnosed with SBA.

\section{Materials and Methods}

\subsection{Patients and Study Design}

From 2004 to 2020, all individuals diagnosed with a small bowel adenocarcinoma (SBA) at four Spanish tertiary hospitals were retrospectively recruited. Clinical and demographic data including age, gender and previous gastrointestinal disease associated with an increased risk of SBA (celiac disease, inflammatory bowel disease and cancer hereditary syndromes), as well as personal and family history of cancer, were registered. Tumor characteristics were reported, including the location, diagnostic stage (TNM), histologic features and grade of differentiation. The type of treatment, follow-up and survival information were also collected. The study was approved by the Hospital Clinic de Barcelona Research Ethics Committee (reference: 2015/0864) and informed consent from individual participants was required.

All tumors underwent mismatch repair (MMR) deficiency testing by immunostaining, including the evaluation of MLH1, MSH2, MSH6 and PMS2 protein expression as previously described [18]. Germline MMR mutational analysis was driven by identification of tumor MMR deficiency. MMR germline genetic testing was performed on germline DNA isolated from peripheral blood leukocytes by both multiple ligation probe amplification analysis and direct sequencing if the patient was alive. When peripheral blood was not available, DNA was extracted from paraffin non-tumoral intestinal tissue. In most patients, a single gene analysis was performed based on the specific loss of protein expression; however, in a few cases, multigene testing was performed through a commercial panel (Trusight Cancer v1, Illumina Inc., San Diego, CA, USA) involving the most frequent hereditary cancer-related genes. LS was diagnosed if a germline pathogenic variant (class 4 and 5 according to InSiGHT classification guidelines) [19] in one of the mismatch repair genes (MLH1, MSH2, MSH6, PMS2 and 3' end EPCAM deletions) was confirmed [19].

\subsection{Statistical Analysis}

A descriptive analysis was performed. Categorical variables were summarized by proportions and quantitative continuous variables by median and interquartile range (IQR) for non-normally distributed variables, and mean and standard deviation (SD) for normally distributed variables. When information was missing, the denominator 
accounted for patients with available data. Comparisons between categorical data were performed using Fisher's exact test. For numerical data, comparisons were performed with the Student's t-test for parametric and the Mann-Whitney U test for nonparametric data. Overall survival curves were calculated using the Kaplan-Meier method and compared with log-rank test. All calculations were performed with the 22.0 SPSS software package (IBM SPSS Statistics for Window, Version 22.0. Armonk, NY, USA). All tests were two-sided and a $p$-value of less than 0.05 was considered statistically significant.

\section{Results}

\subsection{General Characteristics}

A total of 94 patients with SBA were diagnosed between 2004 and 2020. Demographic and clinical characteristics of the entire cohort are detailed in Table 1.

Table 1. Patient and tumor characteristics compared between MMR tumor profile.

\begin{tabular}{|c|c|c|c|c|}
\hline Characteristics & $\begin{array}{l}\text { MMR Proficient } \\
\text { Tumor }(n=74)\end{array}$ & $\begin{array}{l}\text { MMR Deficient } \\
\text { Tumor }(n=20)\end{array}$ & $\begin{array}{c}p \\
\text { Value }\end{array}$ & Total Patients $(n=94)$ \\
\hline Male sex, $n(\%)$ & $44(59.5)$ & $12(60)$ & 0.136 & $52(55.3)$ \\
\hline Clinical diagnostic criteria for $\mathbf{L S} * n(\%)$ & $2(2.7)$ & $4(20)$ & 0.018 & $6(6.4)$ \\
\hline Median age at diagnosis, y (IQR) & $68.5(54.8-77)$ & $58(44.5-69)$ & 0.047 & $65.5(53.8-75.3)$ \\
\hline $\begin{array}{c}\text { Stage } \\
\text { I-II, } n(\%) \\
\text { III-IV, } n(\%)\end{array}$ & $\begin{array}{l}30(45.5) \\
36(54.5)\end{array}$ & $\begin{array}{c}9(45) \\
11(55)\end{array}$ & 1 & $\begin{array}{l}39(45.3) \\
47(54.7)\end{array}$ \\
\hline $\begin{array}{c}\text { Histological grade } \\
\text { G1, } n(\%) \\
\mathrm{G} 2, n(\%) \\
\mathrm{G} 3, n(\%)\end{array}$ & $\begin{array}{l}18(27.3) \\
25(37.9) \\
23(34.8)\end{array}$ & $\begin{array}{l}5(25) \\
7(35) \\
8(40)\end{array}$ & 0.915 & $\begin{array}{c}23(26.7) \\
32(37.2) \\
31(36)\end{array}$ \\
\hline $\begin{array}{c}\text { Location } \\
\text { Duodenum, } n(\%) \\
\text { Jejunum, } n(\%) \\
\text { Ileum, } n(\%)\end{array}$ & $\begin{array}{c}31(42.5) \\
19(26) \\
23(31.5)\end{array}$ & $\begin{array}{c}10(50) \\
9(45) \\
1(5)\end{array}$ & 0.020 & $\begin{array}{l}41(44.1) \\
28(30.1) \\
24(25.8)\end{array}$ \\
\hline $\begin{array}{c}\text { Surgical Intervention, } n(\%) \\
\text { With curative intention, } n(\%)\end{array}$ & $\begin{array}{l}65(87.8) \\
47(63.5)\end{array}$ & $\begin{array}{l}20(100) \\
18(90)\end{array}$ & $\begin{array}{l}0.197 \\
0.028\end{array}$ & $65(69.5)$ \\
\hline Chemotherapy, $n(\%)$ & $36(48.6)$ & $11(55)$ & 0.802 & $47(50)$ \\
\hline SBA mortality, $n(\%)$ & $39(52.7)$ & $5(25)$ & 0.042 & $44(46.8)$ \\
\hline Median age SBA mortality, y (IQR) & $72(58-80)$ & $60(58.5-85.5)$ & 0.956 & $71.5(58.25-80)$ \\
\hline Five-year overall survival (\%) & $15(20.3)$ & $11(55)$ & 0.004 & $26(27.7)$ \\
\hline Mean overall survival, y (95\% CI) & $7.121(5.20-9.04)$ & $6.57(4.84-8.30)$ & 0.073 & $7.286(5.69-8.88)$ \\
\hline Five-year SBA-free survival (\%) & $12(16.2)$ & $10(50)$ & 0.005 & $22(23.4)$ \\
\hline Mean SBA-free survival, y (95\% CI) & $5.96(4.18-7.75)$ & $6.79(4.66-8.93)$ & 0.048 & $6.86(5.21-8.51)$ \\
\hline
\end{tabular}

* Amsterdam and or Bethesda criteria. $n$, number; MMR, mismatch repair system; LS, Lynch syndrome; y, years; SBA, small bowel adenocarcinoma.

The median age at SBA diagnosis was 65.5 (IQR 53.75-75.25) years old and $52(55.3 \%)$ patients were male. SBA risk factors were identified: two (2.1\%) patients had personal history of celiac disease, five (5.3\%) had inflammatory bowel disease (four Crohn's disease and one ulcerative colitis) and one $(1.1 \%)$ had familial adenomatous polyposis syndrome with a known pathogenic mutation on the APC gene. No other hereditary syndrome was previously known. Twenty-seven (28.7\%) patients presented with other metachronous cancers. A family history of cancer was reported in 36 (38.3\%) patients. Six cases met clinical diagnostic criteria for LS (four cases fulfilled Amsterdam II criteria and two revised Bethesda criteria) but LS was not suspected prior to the diagnosis of SBA. 


\subsection{Tumor Mismatch Repair Analysis}

MMR tumor testing by immunohistochemistry was performed for the 94 tumors (Table 1). We identified 20 (21.3\%) MMRd tumors (Figure 1). Seven (35\%) tumors presented a loss of MLH1 and PSM2 protein expression, eight (8.5\%) showed a loss of expression of MSH2 and MSH6, two (10\%) had an isolated loss of MLH1, one (5\%) had an isolated loss of MSH2 and two (10\%) had an isolated loss of PMS2. For patients with MMRd tumors, the median age at diagnosis was 58 (IQR 44.5-68.75) years. One patient with a tumor with loss of expression of MLH1 and PMS2 had celiac disease; none of the others had SBA-related diseases. The majority of tumors were proximal: $10(50 \%)$ in the duodenum, nine $(45 \%)$ in the jejunum and only one (5\%) in the ileum. Most MMRd tumors $(11 / 20)$ were diagnosed in advanced stages (10 (50\%) III, 1 (5\%) IV).
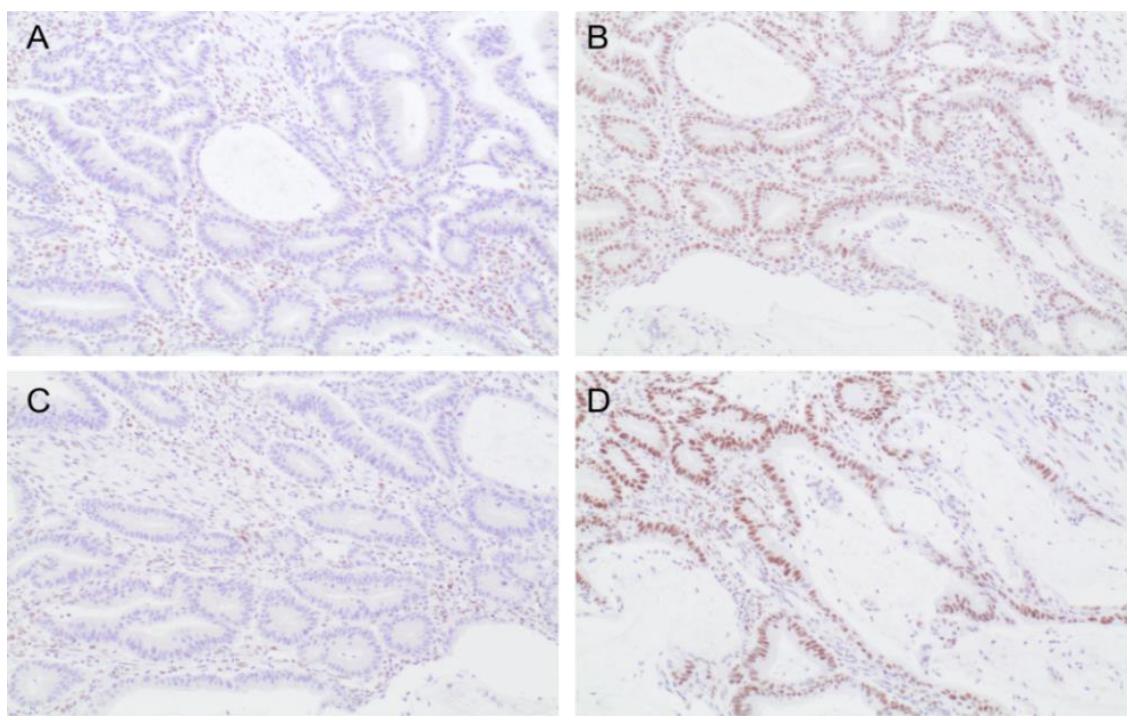

Figure 1. Small bowel adenocarcinoma mismatch repair (MMR) testing by immunostaining $(200 \times)$ showing: (A) MSH1 deficient protein, (B) MSH2 proficient protein, (C) MSH6 proficient protein and (D) PMS2 deficient protein.

In comparison with patients with MMR proficient tumors, those with MMRd tumors were significantly younger (median age 58 years vs. 68.5 years, respectively, $p=0.047$ ) and predominantly located proximally (duodenum and jejunum 19 (95\%) vs. 50 (67.6\%), $p=0.020)$. There was no difference in either gender, stage at diagnosis or histological grade. However, MMR deficient tumors had a lower cancer mortality ( $25 \%$ vs. $52.7 \%$, respectively, $p=0.042)$, with a significantly higher cancer-free survival (6.79 (95\% confident interval (CI) $4.66-8.93)$ vs. $5.96(95 \%$ CI 4.18-7.75), $p=0.048)$ and five-year overall survival ( $55 \%$ vs. $20.3 \%, p=0.04$ ) (Table 1 and Figure 2). 


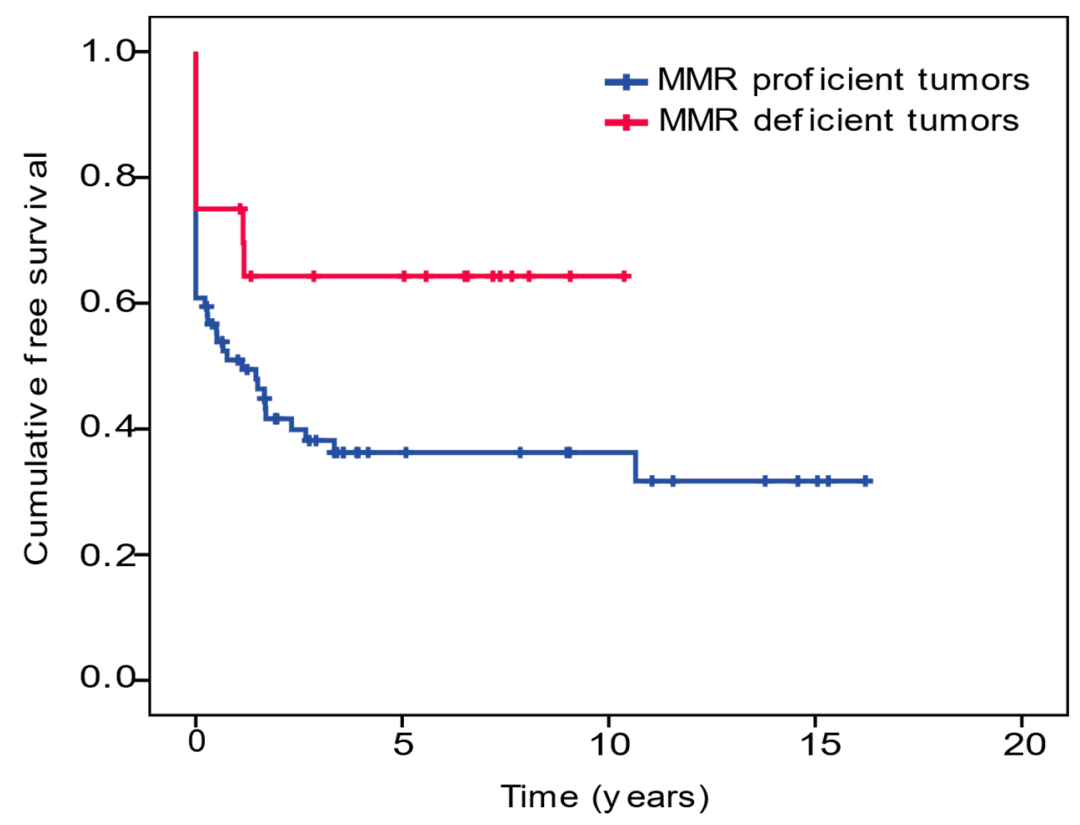

Figure 2. Kaplan-Meyer curves comparing the small-bowel-adenocarcinoma-free survival rate of individuals with a mismatch repair (MMR) proficient and MMR deficient tumors. MMR deficient tumors have a higher mean cancer-free survival: 6.79 (4.66-8.93) years compared to $5.96(4.18-7.75)$ years in MMR proficient tumors $(p=0.048)$.

\subsection{MMR Germline Genetic Analysis}

We performed a germline genetic study in $15 / 20$ patients with MMRd tumors. In the remaining $5 / 20$ cases, we extracted DNA from formalin-fixed paraffin-embedded nontumoral intestinal tissue, but the poor condition of the sample prevented the performing of a germline study.

In $9 / 15(60 \%)$ patients, a pathogenic germline genetic variant was found, leading to the diagnosis of LS: three (20\%) in MLH1, four (26.7\%) in MSH2, one (6.7\%) in MSH6 and one $(6.7 \%)$ in PMS2 (Table 2).

Among the nine patients with LS, seven (77\%) had personal or family history of cancer. Four $(44 \%)$ individuals had a personal history of colorectal cancer under 50 years old fulfilling the revised Bethesda criteria, while one patient also fulfilled the Amsterdam II criteria. In the other three cases, there was a family history of LS-related tumors but without fulfilling the clinical diagnostic criteria for LS (Table 2).

The median age at SBA diagnosis was 51 (IQR 43-69) years. All tumors had a proximal location: four $(44.5 \%)$ at the duodenum and five $(55.6 \%)$ at the jejunum. Four $(44.5 \%)$ patients were diagnosed in a stage II and five $(55.6 \%)$ in a stage III. All cases were surgically treated but one tumor was unresectable and the patient died. A second patient died of prostate cancer progression. 
Table 2. Patients and tumor characteristics from MMR deficient tumors.

\begin{tabular}{|c|c|c|c|c|c|c|c|c|c|c|}
\hline Sex & $\begin{array}{l}\text { SBA Risk } \\
\text { Factors }\end{array}$ & $\begin{array}{l}\text { Family History of } \\
\text { Cancer }\end{array}$ & $\begin{array}{l}\text { Metachronous } \\
\text { Neoplasm }\end{array}$ & $\begin{array}{c}\text { Age at } \\
\text { Diagnosis (y) }\end{array}$ & Location & TNM & Stage & $\begin{array}{l}\text { Deficient MMR } \\
\text { Proteins }\end{array}$ & Germline MMR Study & Evolution \\
\hline Male & No & $\begin{array}{c}\text { Two 1st-degree } \\
\text { relatives: bladder } 40 \\
\text { y-o and pancreatic } \\
\text { cancer } 38 \text { y-o }\end{array}$ & CRC 43 y-o & 51 & Jejunum & T3N1M0 & III & MLH1/PMS2 & $\begin{array}{c}M L H 1 \\
\text { (c.1644 C>G; } \\
\text { p. Tyr548Ter) }\end{array}$ & Alive \\
\hline Female & No & $\begin{array}{l}\text { 1st-degree relative } \\
\text { CRC } 33 \text { y-o; } \\
\text { 3rd-degree relative } \\
\text { gastric cancer } 45 \text { y-o }\end{array}$ & No & 67 & Jejunum & T3N0M0 & II & MLH1/PMS2 & $\begin{array}{c}M L H 1 \\
\text { (c.350C > T; } \\
\text { p. Thr117Met) }\end{array}$ & Alive \\
\hline Female & No & No & CRC 49 y-o & 69 & Duodenum & T3N0M0 & II & MLH1/PMS2 & $\begin{array}{c}M L H 1 \\
\text { (c. } 306+5 \mathrm{G}>\mathrm{A})\end{array}$ & Alive \\
\hline Male & No & $\begin{array}{l}\text { Two 1st-degree } \\
\text { relatives CRC: } 23 \text { and } \\
50 \mathrm{y}-\mathrm{o}\end{array}$ & CRC 41 y-o & 42 & Jejunum & T4N1M0 & III & MSH2/MSH6 & $\begin{array}{c}\text { MSH2 } \\
\text { (c.1861C>T; } \\
\text { p. Arg621Ter) }\end{array}$ & Alive \\
\hline Male & No & No & No & 44 & Duodenum & T4N1M0 & III & MSH2/MSH6 & $\begin{array}{c}M S H 2 \\
\text { (c.927dupAG) }\end{array}$ & Dead \\
\hline Male & No & $\begin{array}{l}\text { 1st-degree relative } \\
\text { CRC } 67 \mathrm{y} \text {-o }\end{array}$ & No & 46 & Ileum & T4N1M0 & III & MSH2/MSH6 & $\begin{array}{c}\text { MSH2 } \\
\text { (c. } 842 \mathrm{C}>\mathrm{G} \text {; } \\
\text { p. Ser281Ter) }\end{array}$ & Alive \\
\hline Female & No & $\begin{array}{l}\text { 1st-degree relative } \\
\text { CRC } 60 \text { y-o }\end{array}$ & $\begin{array}{l}\text { Intestinal } \\
\text { lymphoma }\end{array}$ & 82 & Jejunum & T3N0M0 & II & MSH2/MSH6 & $\begin{array}{c}\text { MSH6 } \\
\text { (c.2188dupT; } \\
\text { p. Tyr730LeufsTer26) }\end{array}$ & Alive \\
\hline Female & No & $\begin{array}{l}\text { 1st-degree relative } \\
\text { bladder cancer } 66 \text { y-o; } \\
\text { 2nd-degree relative } \\
\text { ureter cancer } 67 \mathrm{a}\end{array}$ & No & 39 & Jejunum & T3N0M0 & II & PMS2 & $\begin{array}{c}\text { PMS2 } \\
\text { (c.1831dup; p. Ile611fs) }\end{array}$ & Alive \\
\hline
\end{tabular}


Table 2. Cont.

\begin{tabular}{|c|c|c|c|c|c|c|c|c|c|c|}
\hline Sex & $\begin{array}{l}\text { SBA Risk } \\
\text { Factors }\end{array}$ & $\begin{array}{c}\text { Family History of } \\
\text { Cancer }\end{array}$ & $\begin{array}{l}\text { Metachronous } \\
\text { Neoplasm }\end{array}$ & $\begin{array}{c}\text { Age at } \\
\text { Diagnosis (y) }\end{array}$ & Location & TNM & Stage & $\begin{array}{c}\text { Deficient MMR } \\
\text { Proteins }\end{array}$ & Germline MMR Study & Evolution \\
\hline Female & $\begin{array}{l}\text { Celiac } \\
\text { Disease }\end{array}$ & $\begin{array}{c}\text { Four } 2 \text { nd-degree } \\
\text { relatives } \\
\text { CRC }>85 \text { y-o }\end{array}$ & No & 60 & Jejunum & T3N0M0 & II & MLH1/PMS2 & Negative & Alive \\
\hline Female & No & No & No & 71 & Jejunum & T3N0M0 & II & MLH1 & Negative & Alive \\
\hline Female & No & $\begin{array}{l}\text { 1st-degree relative } \\
\text { endometrium } 63 \text { y-o }\end{array}$ & $\begin{array}{l}\text { Follicular } \\
\text { lymphoma }\end{array}$ & 37 & Duodenum & T3N0M0 & II & MLH1/PMS2 & Negative & Alive \\
\hline Female & No & No & No & 57 & Duodenum & T4N1M1 & IV & MSH2/MSH6 & Negative & Dead \\
\hline Female & No & $\begin{array}{c}\text { Three 2nd-degree } \\
\text { relatives: leukemia, } \\
\text { ovarian cancer, renal } \\
\text { cancer }\end{array}$ & No & 43 & Duodenum & T4N0M0 & II & MSH2/MSH6 & Negative & Alive \\
\hline Female & No & No & $\begin{array}{c}\text { CRC } 42 \text { y-o, } \\
\text { Hodgkin } \\
\text { lymphoma } 55 \\
\text { y-o }\end{array}$ & 59 & Duodenum & T3N1M0 & III & MLH1/PMS2 & NA & Dead \\
\hline Male & No & $\begin{array}{l}\text { Relative prostate } \\
\text { cancer }\end{array}$ & No & 90 & Jejunum & T3N1M0 & III & MSH2 & NA & Dead \\
\hline Male & No & $\begin{array}{l}\text { 3rd-degree relative } \\
\text { hepatic cancer }\end{array}$ & No & 53 & Duodenum & T3N1M0 & III & MSH2/MSH6 & NA & Alive \\
\hline Female & No & $\begin{array}{l}\text { 1st-degree relative } \\
\text { unknown cancer } 54 \\
\text { y-o; two } 2 \text { nd-degree } \\
\text { relatives: gastric and } \\
\text { intestinal cancer }\end{array}$ & No & 56 & Duodenum & T3N0M0 & II & PMS2 & NA & Dead \\
\hline
\end{tabular}




\section{Discussion}

This study evaluates the identification of LS patients based on tumor MMR analysis among patients with SBA. Our results show a 21.3\% (20/95) prevalence of MMRd tumors and a $10.1 \%(9 / 89)$ prevalence of LS among all SBA cases. Of patients with a MMRd tumor, a germline mutation was identified in $60 \%$ of cases.

LS is one of the most common causes of hereditary cancer [20]. These families can benefit from preventive strategies to reduce the incidence and mortality of cancer. In colorectal cancer, universal screening strategies are recommended to improve the diagnosis of LS by performing tumor MMR testing in all cases [8]. However, LS continues to be an underdiagnosed syndrome and our results support this fact. Seven patients diagnosed with a germline mutation had a personal and/or family history of colorectal cancer at early ages and fulfilled the diagnostic criteria to suspect this syndrome. However, these families were not tested for LS before the diagnosis of SBA. Accordingly, universal testing with MMR in all SBA should be recommended.

Moreover, although the incidence of SBA is low (1\%) [1] in LS when compared to colorectal cancer (up to $45 \%$ lifetime risk) [21], Moreira et al. showed a 13.8\% (1386/10019) of MMR deficiency colorectal tumors, with only $20 \%$ (289/1386) of them diagnosed with LS [8]. Our results show a better performance of a universal MMR testing strategy in SBA, as more than $20 \%$ were MMR deficient and up to $60 \%$ were diagnosed with a pathogenic MMR germline mutation.

On the other hand, in LS asymptomatic patients, international guidelines do not recommend systematic surveillance of the small bowel [22]. However, some studies have suggested the use of endoscopic capsule or computed tomography enteroclysis as surveillance techniques, but the low rate of SBA detection has not justified its benefit $[12,23,24]$. Gastroscopy with a careful duodenal exploration has also been evaluated for the prevention of both gastric and SBA, and the proximal location of SBA in LS supported by our results encourages the performance of prospective studies to evaluate its convenience.

We found significant differences when comparing MMR proficient and deficient tumors. Firstly, MMR deficient tumors are diagnosed at a younger age and at a proximal location. Secondly, although no differences were found on stage and treatment, we found a higher curative intention rate and a higher cancer-free survival. These results support the use of a universal MMR study as an independent factor for better prognosis [13,14].

Moreover, MMRd tumors can express programmed death ligand 1 (PD-L1) and its used as a biomarker to identify immunotherapy-responsive patients [25]. In SBA, the phase II KEYNOTE-158 showed a clinical benefit of anti-PD-1 therapy with pembrolizumab among patients with a histologically confirmed advanced-unresectable and/or metastatic MMRd SBA [26]. The detection of MMR tumors has a clinical implication on treatment decision, reinforcing the importance of universal MMR testing in SBA.

We are aware of some limitations of the study, mainly due to the retrospective design. Firstly, genetic testing was not performed on all patients, although LS with MMR proficient tumors is expected to be exceptional. We must not dismiss that with next-generation gene sequencing panels; a direct analysis of patients with SBA could be also a good strategy to identify LS patients, if accessible. Secondly, the low prevalence of SBA has led to a small number of patients, although we could prove a statistical difference existed between the groups.

\section{Conclusions}

SBA is a rare disease with a poor prognosis. Identifying MMR deficient tumors can predict a better prognosis and identify immunotherapy-responsive patients having immediate clinical implications. Our data shows that $20 \%$ of SBA patients display MMRd and more than a half are due to LS MMR germline mutations.

Diagnosis of patients with LS is crucial to identifying pre-symptomatic relatives at risk and to establish preventive measures to decrease morbidity and mortality per cancer. 
In this low-prevalence disease, we encourage universal tumor MMR testing implementation to improve treatment decisions and to increase the identification of LS families.

Author Contributions: Conceptualization, A.S. and L.M. (Leticia Moreira); methodology, A.S. and L.M. (Leticia Moreira); software, A.S. and L.M. (Leticia Moreira); validation, A.S. and L.M. (Leticia Moreira); formal analysis, A.S. and L.M. (Leticia Moreira); supervision, A.S. and L.M. (Leticia Moreira); investigation, A.S., L.B., C.A.-U., G.H. and L.A.; data curation, A.S. and A.B.; writingoriginal draft preparation, A.S., A.B., C.H.-P. and L.M. (Leticia Moreira); writing-review, editing and visualization: A.S., L.B., M.C., A.B., C.A-U., G.H., L.A., S.C., J.L., C.H.-P., M.I., L.R.-S., G.J., L.M. (Lorena Moreno), T.O., C.B., M.P., A.C., S.C.-B., F.B., L.M. (Leticia Moreira). All authors have read and agreed to the published version of the manuscript.

Funding: This study was funded by the CERCA Program (Generalitat de Catalunya) and Agència de Gestió d'Ajuts Universitaris i de Recerca (Generalitat de Catalunya, GRPRE 2017SGR21, GRC 2017SGR653). CIBEREHD is funded by the Instituto de Salud Carlos III.

Institutional Review Board Statement: Institutional Review Board Statement: The study was conducted according to the guidelines of the Declaration of Helsinki and approved by the Institutional Review Board (or Ethics Committee) of Hospital Clínic in Barcelona (register number 2015/0864, date of approval 22/10/2015).

Informed Consent Statement: Informed consent was obtained from all subjects involved in the study.

Data Availability Statement: The data that support the findings of this study are available from the corresponding author upon reasonable request.

Acknowledgments: The authors would like to thank the Department of Pathology for their collaboration and technical support. The authors are sincerely grateful to all centers for their collaboration in this study.

Conflicts of Interest: The authors declare no conflict of interest.

\section{References}

1. Aparicio, T.; Zaanan, A.; Mary, F.; Afchain, P.; Manfredi, S.; Evans, T.R.J. Small Bowel Adenocarcinoma. Gastroenterol. Clin. N. Am. 2016, 45, 447-457. [CrossRef]

2. Neugut, A.I.; Jacobson, J.S.; Suh, S.; Mukherjee, R.; Arber, N. The epidemiology of cancer of the small bowel. Cancer Epidemiol. Biomark. Prev. 1998, 7, 243-251.

3. Brueckl, W.M.; Heinze, E.; Milsmann, C.; Wein, A.; Koebnick, C.; Jung, A.; Croner, R.S.; Brabletz, T.; Kirchner, T.; Hahn, E.G.; et al. Prognostic significance of microsatellite instability in curatively resected adenocarcinoma of the small intestine. Cancer Lett. 2004, 203, 181-190. [CrossRef]

4. Chirita-Emandi, A.; Andreescu, N.; Zimbru, C.G.; Tutac, P.; Arghirescu, S.; Serban, M.; Puiu, M. Challenges in reporting pathogenic/potentially pathogenic variants in 94 cancer predisposing genes-in pediatric patients screened with NGS panels. Sci. Rep. 2020, 10, 223. [CrossRef] [PubMed]

5. Shenoy, S. Genetic risks and familial associations of small bowel carcinoma. World J. Gastrointest. Oncol. 2016, 8, 509-519. [CrossRef] [PubMed]

6. Aparicio, T.; Zaanan, A.; Svrcek, M.; Laurent-Puig, P.; Carrere, N.; Manfredi, S.; Locher, C.; Afchain, P. Small bowel adenocarcinoma: Epidemiology, risk factors, diagnosis and treatment. Dig. Liver Dis. 2014, 46, 97-104. [CrossRef]

7. Pan, S.Y.; Morrison, H. Epidemiology of cancer of the small intestine. World J. Gastrointest. Oncol. 2011, 3, 33-42. [CrossRef]

8. Moreira, L.; Balaguer, F.; Lindor, N.; De La Chapelle, A.; Hampel, H.; Aaltonen, L.A.; Hopper, J.L.; Le Marchand, L.; Gallinger, S.; Newcomb, P.A.; et al. Identification of Lynch syndrome among patients with colorectal cancer. JAMA 2012, 308, 1555-1565. [CrossRef] [PubMed]

9. Lynch, H.T.; Snyder, C.L.; Shaw, T.G.; Heinen, C.D.; Hitchins, M.P. Milestones of Lynch syndrome: 1895-2015. Nat. Rev. Cancer 2015, 15, 181-194. [CrossRef]

10. Moreira, L.; Muñoz, J.; Cuatrecasas, M.; Quintanilla, I.; Leoz, M.L.; Carballal, S.; Ocaña, T.; López-Cerón, M.; Pellise, M.; Castellví-Bel, S.; et al. Prevalence of Somatic MutL Homolog 1 Promoter Hypermethylation in Lynch Syndrome Colorectal Cancer. Cancer 2015, 121, 1395-1404. [CrossRef]

11. Ten Kate, G.L.; Kleibeuker, J.H.; Nagengast, F.M.; Craanen, M.; Cats, A.; Menko, F.H.; Vasen, H.F.A. Is surveillance of the small bowel indicated for Lynch syndrome families? Gut 2007, 56, 1198-1201. [CrossRef] [PubMed]

12. Haanstra, J.F.; Al-Toma, A.; Dekker, E.; Vanhoutvin, S.A.L.W.; Nagengast, F.M.; Mathus-Vliegen, E.M.; Van Leerdam, M.E.; De Vos Tot Nederveen Cappel, W.H.; Sanduleanu, S.; Veenendaal, R.A.; et al. Prevalence of small-bowel neoplasia in Lynch syndrome assessed by video capsule endoscopy. Gut 2015, 64, 1578-1583. [CrossRef] [PubMed] 
13. Planck, M.; Ericson, K.; Piotrowska, Z.; Halvarsson, B.; Rambech, E.; Nilbert, M. Microsatellite instability and expression of MLH1 and MSH2 in carcinomas of the small intestine. Cancer 2003, 97, 1551-1557. [CrossRef] [PubMed]

14. Aparicio, T.; Svrcek, M.; Zaanan, A.; Beohou, E.; Laforest, A.; Afchain, P.; Mitry, E.; Taieb, J.; Di Fiore, F.; Gornet, J.M.; et al. Small bowel adenocarcinoma phenotyping, a clinicobiological prognostic study. Br. J. Cancer 2013, 109, 3057-3066. [CrossRef]

15. Wheeler, J.M.D.; Warren, B.F.; Mortensen, N.J.M.C.; Kim, H.C.; Biddolph, S.C.; Elia, G.; Beck, N.E.; Williams, G.T.; Shepherd, N.A.; Bateman, A.C.; et al. An insight into the genetic pathway of adenocarcinoma of the small intestine. Gut 2002, 50, 218-223. [CrossRef]

16. Warth, A.; Kloor, M.; Schirmacher, P.; Bla, H. Genetics and epigenetics of small bowel adenocarcinoma: The interactions of CIN, MSI, and CIMP. Mod. Pathol. 2011, 24, 564-570. [CrossRef] [PubMed]

17. Schulmann, K.; Brasch, F.E.; Kunstmann, E.; Engel, C.; Pagenstecher, C.; Vogelsang, H.; Krüger, S.; Vogel, T.; Knaebel, H.P.; Rüschoff, J.; et al. HNPCC-associated small bowel cancer: Clinical and molecular characteristics. Gastroenterology 2005, 128, 590-599. [CrossRef]

18. Pérez-Carbonell, L.; Ruiz-Ponte, C.; Guarinos, C.; Alenda, C.; Payá, A.; Brea, A.; Egoavil, C.M.; Castillejo, A.; Barberá, V.M.; Bessa, $X$.; et al. Comparison between universal molecular screening for Lynch syndrome and revised Bethesda guidelines in a large population-based cohort of patients with colorectal cancer. Gut 2012, 61, 865-872. [CrossRef]

19. Thompson, B.A.; Spurdle, A.B.; Plazzer, J.P.; Greenblatt, M.S.; Akagi, K.; Al-Mulla, F.; Bapat, B.; Bernstein, I.; Capellá, G.; Den Dunnen, J.T.; et al. Application of a 5-tiered scheme for standardized classification of 2360 unique mismatch repair gene variants in the InSiGHT locus-specific database. Nat. Genet. 2014, 46, 107-115. [CrossRef]

20. Nagy, R.; Sweet, K.; Eng, C. Highly penetrant hereditary cancer syndromes. Oncogene 2004, 23, 6445-6470. [CrossRef] [PubMed]

21. Møller, P.; Seppälä, T.; Bernstein, I.; Holinski-Feder, E.; Sala, P.; Evans, D.G.; Lindblom, A.; Macrae, F.; Blanco, I.; Sijmons, R.; et al. Cancer incidence and survival in Lynch syndrome patients receiving colonoscopic and gynaecological surveillance: First report from the prospective Lynch syndrome database. Gut 2015, 66, 464-472. [CrossRef] [PubMed]

22. van Leerdam, M.E.; Roos, V.H.; van Hooft, J.E.; Balaguer, F.; Dekker, E.; Kaminski, M.F.; Latchford, A.; Neumann, H.; Ricciardiello, L.; Rupinska, M.; et al. Endoscopic management of Lynch syndrome and of familial risk of colorectal cancer: European Society of Gastrointestinal Endoscopy (ESGE) Guideline. Endoscopy 2019, 51, 1082-1093. [CrossRef] [PubMed]

23. Haanstra, J.F.; Kleibeuker, J.H.; Koornstra, J.J. Role of new endoscopic techniques in Lynch syndrome. Fam. Cancer 2013, 12, 267-272. [CrossRef]

24. Saurin, J.C.; Pilleul, F.; Soussan, E.B.; Maniere, T.; D’Halluin, P.N.; Gaudric, M.; Cellier, C.; Heresbach, D.; Gaudin, J.L.; Capsule Commission of the French Society of Digestive Endoscopy (SFED). Small-bowel capsule endoscopy diagnoses early and advanced neoplasms in asymptomatic patients with Lynch syndrome. Endoscopy 2010, 42, 1057-1062. [CrossRef] [PubMed]

25. Noh, B.J.; Hong, S.M.; Jun, S.Y.; Eom, D.W. Prognostic implications of immune classification in a multicentre cohort of patients with small intestinal adenocarcinoma. Pathology 2020, 52, 228-235. [CrossRef] [PubMed]

26. Marabelle, A.; Le, D.T.; Ascierto, P.A.; Di Giacomo, A.M.; De Jesus-Acosta, A.; Delord, J.P.; Geva, R.; Gottfried, M.; Penel, N.; Hansen, A.R.; et al. Efficacy of Pembrolizumab in Patients With Noncolorectal High Microsatellite Instability/ Mismatch Repair-Deficient Cancer: Results From the Phase II KEYNOTE-158 Study. J. Clin. Oncol. 2019, 38, 1-10. [CrossRef] 